\title{
A Flow-Through Membraneless Microfluidic Zinc-air Cell
}

Euth Ortiz-Ortega,,$^{\dagger} \ddagger$ Lucia Díaz-Patiño, ${ }^{\dagger} \ddagger$ José Bejar,,$^{\dagger}$ Gabriel Trejo, ${ }^{\dagger}$ Minerva GuerraBalcázar, ${ }^{\|}$Francisco Espinosa-Magaña, ${ }^{\S}$ Lorena Álvarez-Contreras,,$^{\S}$ Luis Gerardo Arriaga,$^{\dagger}$ and Noé Arjona ${ }^{\dagger *}$

† Centro de Investigación y Desarrollo Tecnológico en Electroquímica S. C., Pedro Escobedo, Querétaro, C. P. 76703, México.

" Facultad de Ingeniería, División de Investigación y Posgrado, Universidad Autónoma de Querétaro, Querétaro, C. P. 76010, México

$\S$ Centro de Investigación en Materiales Avanzados S. C., Complejo Industrial Chihuahua, Chihuahua, C. P. 31136, México

\section{Corresponding authors:}

* N. Arjona, e-mail: wvelazquez@cideteq.mx and noe.arjona@yahoo.com.mx , Phone: +52 442 2116000 ext. 7874. 


\section{Formation of $\alpha-\mathrm{MnO}_{2}$ :}

Peroxydisulfate $\left(\mathrm{S}_{2} \mathrm{O}_{8}{ }^{2-}\right)$ in presence of manganese species reacts to form a $\mathrm{MnO}_{4}{ }^{-}$intermediate (1).

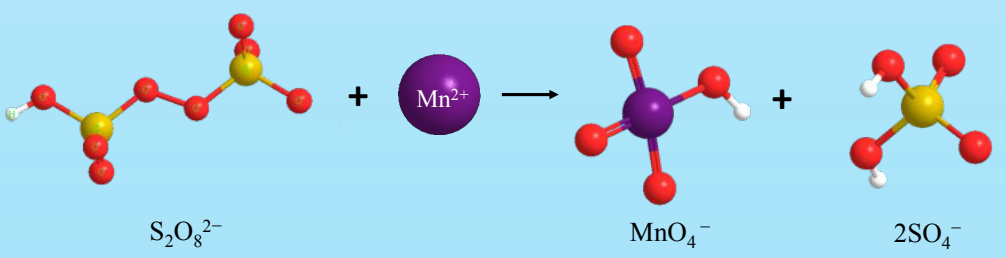

In strong alkaline conditions, the $\mathrm{MnO}_{4}{ }^{-}$intermediate can be oxidized to a $\mathrm{Mn}$ (IV) oxide by the presence of the $\mathrm{SO}_{4}^{-}$specie (2).

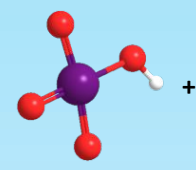

$\mathrm{MnO}_{4}^{-}$

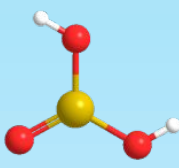

$\mathrm{SO}_{4}^{-}$

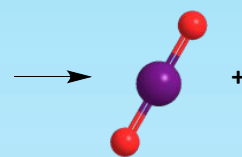

$\mathrm{MnO}_{2}$

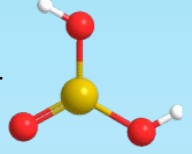

$\mathrm{SO}_{4}{ }^{2-}$

\section{Formation of $\mathrm{MnMn}_{2} \mathrm{O}_{4}$ spinel $\left(\mathrm{Mn}_{3} \mathrm{O}_{4}\right)$ :}

The $\mathrm{MnCl}_{2}$ in presence of $\mathrm{KOH}$ generates (3):

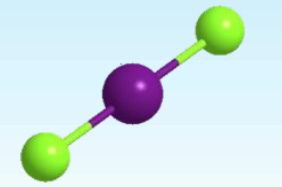

$\mathrm{MnCl}_{2}$

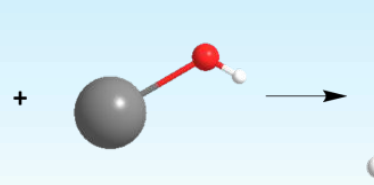

$2 \mathrm{KOH}$

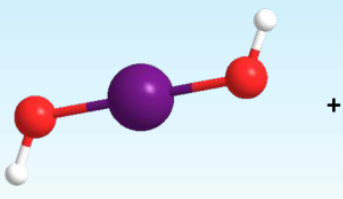

$\mathrm{Mn}(\mathrm{OH})_{2}$

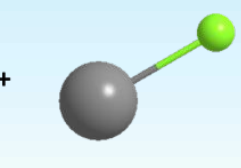

$2 \mathrm{KCl}$

Then, in presence of $\mathrm{H}_{2} \mathrm{O}_{2}(4)$ :

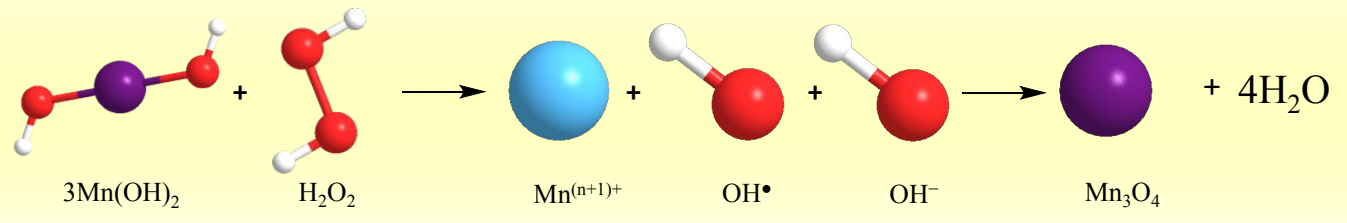

Figure S1. Schematic representation of the formation mechanism of $\alpha-\mathrm{MnO}_{2}$ and $\mathrm{Mn}_{3} \mathrm{O}_{4}$ materials.

The schematic representation of the formation of $\alpha-\mathrm{MnO}_{2}$ and $\mathrm{Mn}_{3} \mathrm{O}_{4}$ materials are presented in Figure S1. Ammonium persulfate was used as the oxidizing agent for $\alpha-\mathrm{MnO}_{2}$ and hydrogen peroxide for $\mathrm{Mn}_{3} \mathrm{O}_{4}$. The formation of $\alpha-\mathrm{MnO}_{2}$ involves the reaction between the peroxydisulfate $\left(\mathrm{S}_{2} \mathrm{O}_{8}{ }^{2-}\right.$, generated from ammonium persulfate) with the $\mathrm{Mn}^{2+}$ specie to form the $\mathrm{MnO}_{4}{ }^{-}$specie (1). ${ }^{1}$ Then, this intermediate is oxidized to $\mathrm{MnO}_{2}$ in presence of the $\mathrm{SO}_{4}^{-}$ specie (2). On the other hand, hydrogen peroxide is a good oxidant in a basic medium. It can transform $\mathrm{Mn}^{2+}$ into $\mathrm{Mn}_{3} \mathrm{O}_{4}$. Firstly, the $\mathrm{Mn}^{2+}$ specie interacts with $\mathrm{KOH}$ to form $\mathrm{Mn}(\mathrm{OH})_{2}(3) .{ }^{2}$ Then, the hydrogen peroxide allows to 
form directly the $\mathrm{Mn}_{3} \mathrm{O}_{4}$ oxide in the presence of $\mathrm{H}_{2} \mathrm{O}_{2}$ (4). ${ }^{3}$ Additionally, it has been reported that in transition metals like $\mathrm{Fe}$ (III), $\mathrm{Cu}$ (II) or $\mathrm{Mn}$ (II) occurs Fenton-like reactions in the presence of $\mathrm{H}_{2} \mathrm{O}_{2}$ and an alkaline medium. ${ }^{3}$ Thus, the formation of $\mathrm{Mn}_{3} \mathrm{O}_{4}$ involves a Fenton type reaction (4). ${ }^{4}$ 


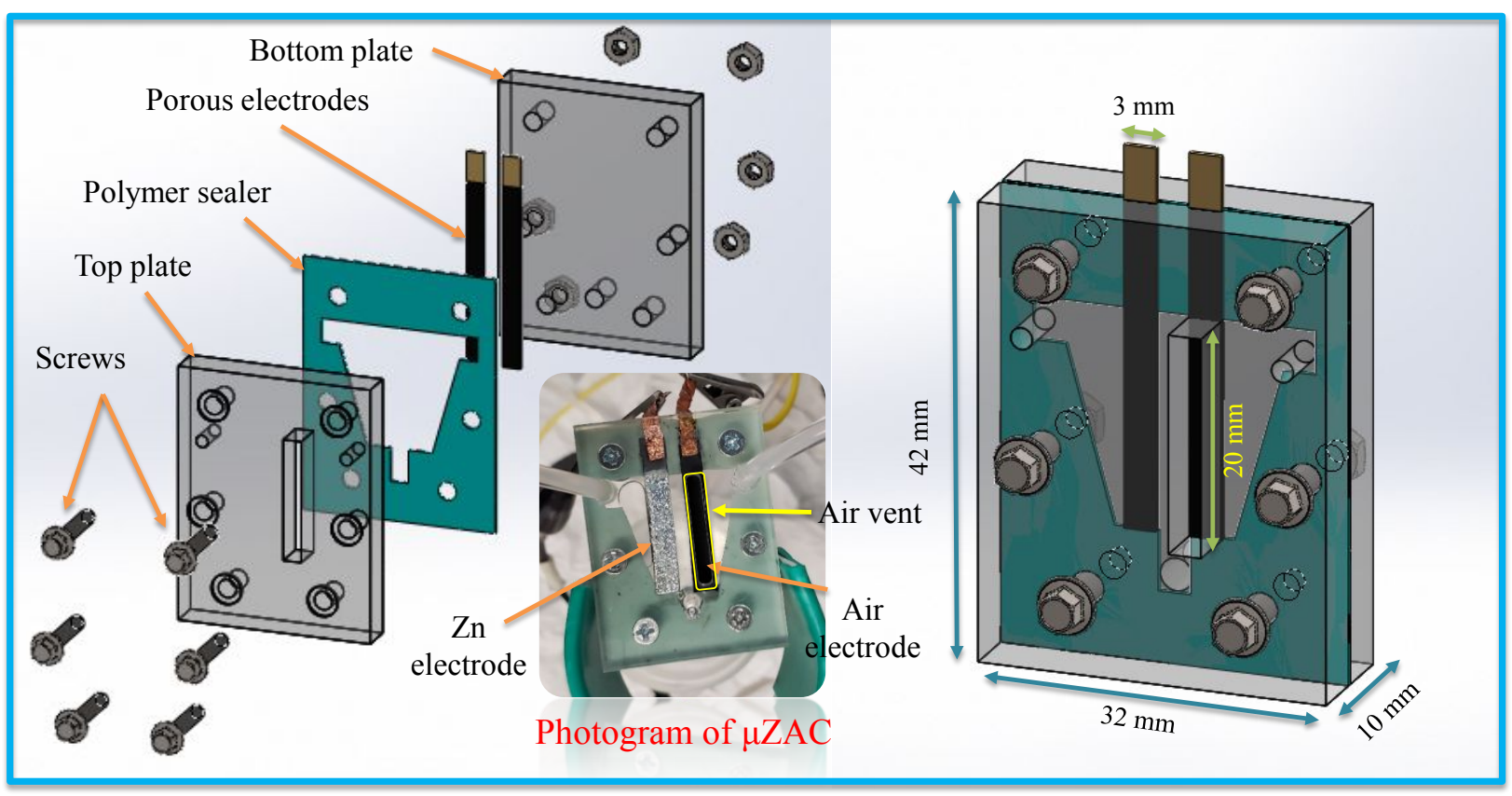

Figure S2. Schematic representation of the $\mu \mathrm{ZAC}$ components and dimensions. A photograph of $\mu \mathrm{ZAC}$ is shown in the inset. The yellow square in the photograph highlights the air vent. 

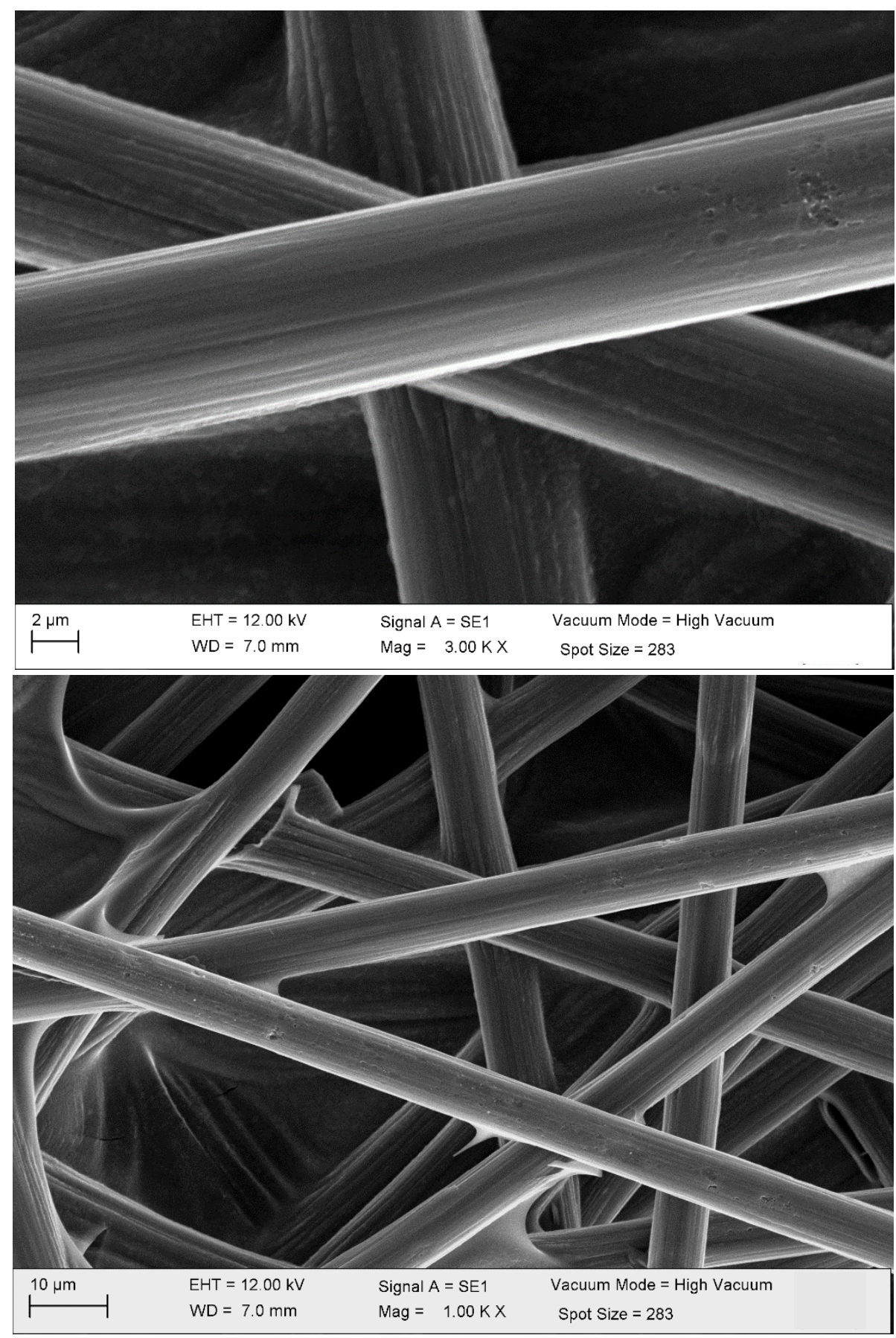

Figure S3. SEM micrographs of naked carbon paper electrodes. 


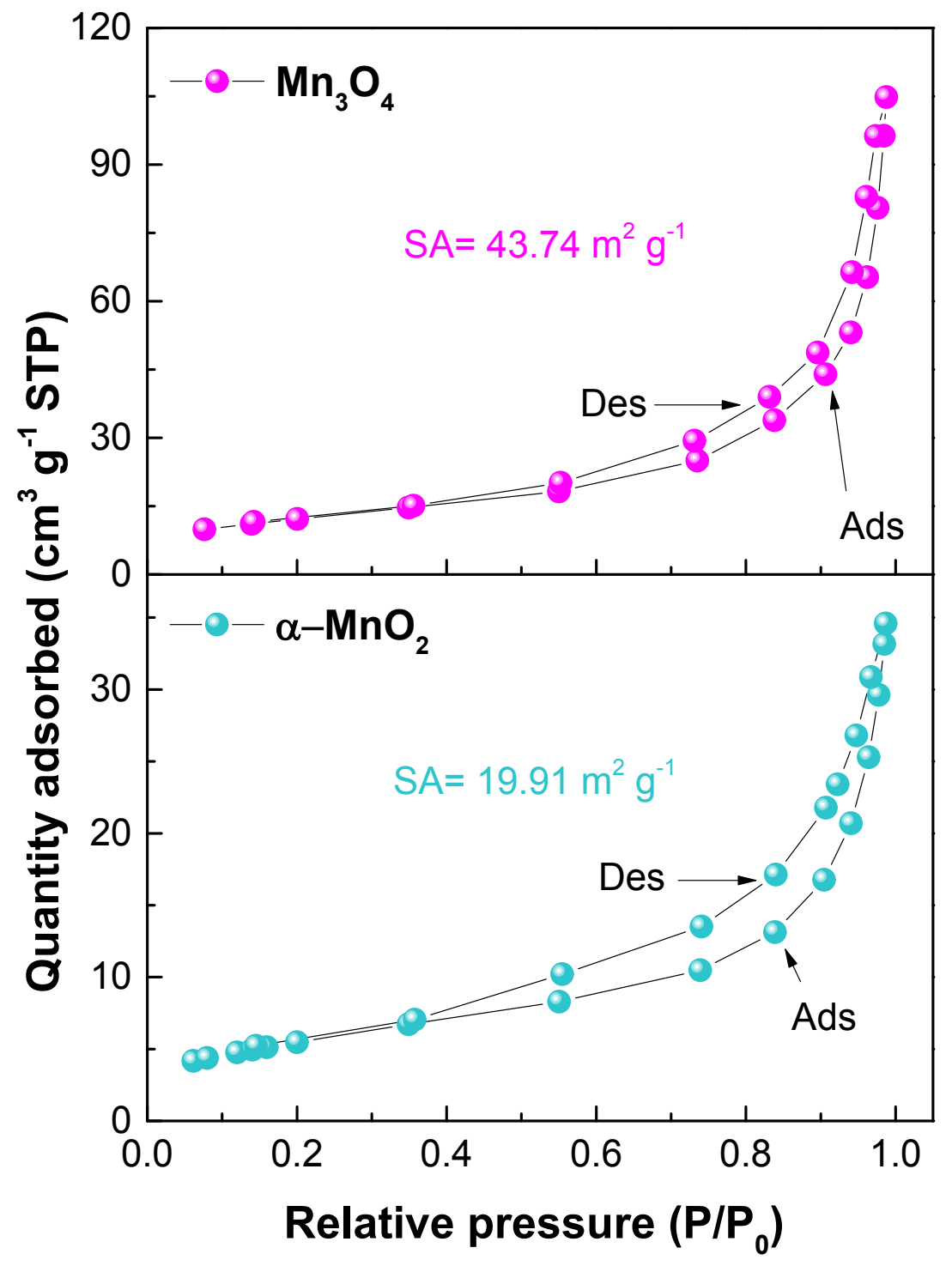

Figure S4. $\mathrm{N}_{2}$ adsorption-desorption isotherms for $\alpha-\mathrm{MnO}_{2}$ and $\mathrm{Mn}_{3} \mathrm{O}_{4}$ materials. BET surface areas are inset. 
TABLE S1. Positions of manganese core-levels found by XPS for $\alpha-\mathrm{MnO}_{2}$, and $\mathrm{Mn}_{3} \mathrm{O}_{4} / \mathrm{C}$.

\begin{tabular}{|c|c|c|c|}
\hline Material & Species & Peak position (eV) & $\mathrm{Mn}^{3+} / \mathrm{Mn}^{4+}$ ratio \\
\hline \multirow{4}{*}{$\alpha-\mathrm{MnO}_{2}$} & $2 \mathrm{p}_{3 / 2} \mathrm{Mn}^{3+}$ & 641.99 & \multirow{4}{*}{0.89} \\
\hline & $2 \mathrm{p}_{3 / 2} \mathrm{Mn}^{4+}$ & 642.95 & \\
\hline & $2 \mathrm{p}_{1 / 2} \mathrm{Mn}^{3+}$ & 653.38 & \\
\hline & $2 \mathrm{p}_{1 / 2} \mathrm{Mn}^{4+}$ & 654.47 & \\
\hline \multirow{6}{*}{$\mathrm{MnO}_{3} \mathrm{O}_{4}$} & $2 \mathrm{p}_{3 / 2} \mathrm{Mn}^{2+}$ & 640.80 & \\
\hline & $2 \mathrm{p}_{3 / 2} \mathrm{Mn}^{3+}$ & 641.45 & \multirow{5}{*}{0.85} \\
\hline & $2 \mathrm{p}_{3 / 2} \mathrm{Mn}^{4+}$ & 642.75 & \\
\hline & $2 \mathrm{p}_{1 / 2} \mathrm{Mn}^{2+}$ & 652.10 & \\
\hline & $2 \mathrm{p}_{1 / 2} \mathrm{Mn}^{3+}$ & 653.38 & \\
\hline & $2 \mathrm{p}_{1 / 2} \mathrm{Mn}^{4+}$ & 654.00 & \\
\hline
\end{tabular}


Video S1. A fan is operating with the $\mu \mathrm{ZAC}$ constructed with the $\mathrm{Zn} / \mathrm{CP} 60 \mathrm{~min}$ as anode and Pt/C as cathode.

Video S2. A LED is operating with the $\mu \mathrm{ZAC}$ constructed with the $\mathrm{Zn} / \mathrm{CP} 60 \mathrm{~min}$ as anode and $\mathrm{Pt} / \mathrm{C}$ as cathode.

\section{References:}

(1) Akiho H., Ito S., Matsuda H., Yoshioka T., Elucidation of the Mechanism of Reaction between $\mathrm{S}_{2} \mathrm{O}_{8}{ }^{2-}$, Selenite and $\mathrm{Mn}^{2+}$ in Aqueous Solution and Limestone-Gypsum FGD Liquor, Environ. Sci. Technol. 2013, 47, 11311-11317.

(2) Ahmed K. A. M., Huang K., Formation of $\mathrm{Mn}_{3} \mathrm{O}_{4}$ Nanobelts Through the Solvothermal Process and their Photocatalytic Property, Arabian J. Chem. 2019, 12, 429-439.

(3) Durmus Z., Kavas H., Baykal A., Toprak M., A Green Chemical Route for the Synthesis of $\mathrm{Mn}_{3} \mathrm{O}_{4}$ Nanoparticles, Cent. Eur. J. Chem. 2009, 7, 555-559.

(4) Moon J., Awano M., Takagi H., Fujishiro Y., Synthesis of Nanocrystalline Manganese Oxide Powders: Influence of Hydrogen Peroxide on Particle Characteristics, J. Mater Res. 1999, 14, 4594-4601. 